\title{
Identification of molecular markers on bovine chromosome 18 associated to calving interval in a Brangus-Ibagé cattle herd
}

\author{
Identificação de marcadores moleculares no cromossomo bovino 18 associados ao intervalo entre \\ partos em um rebanho Brangus-Ibagé
}

\author{
Tania de Azevedo Weimer ${ }^{\mathrm{I}, \mathrm{II}^{*}}$ Clara Sabina Steigleder ${ }^{\mathrm{I}}$ Márcia Silveira Machado ${ }^{\mathrm{III}}$ \\ Sabrina Esteves Matos AlmeidaI João Francisco Coelho Oliveira'II \\ José Carlos Ferrugem Moraes ${ }^{\mathrm{IV}}$ Luis Ernani Henkes $^{\mathrm{V}}$
}

\section{- NOTE -}

\section{ABSTRACT}

In the detection phase of a bovine marker assisted selection program, this paper investigated the genetic variability of three microsatellites on the chromosome 18 (BTA 18). The possible associations between genotypes or alleles of these markers versus weight at first calving and a lifetime calving interval (as indicators of reproductive performance) were evaluated in a beef cattle herd (5/8 Aberdeen Angus $x$ 3/8 Nelore). Eleven alleles were detected in TGLA227 and ILSTSO02 and three in BMS3004, the most frequent being TGLA227*79, ILSTS002*133, ILSTS002*135 and BMS3004*129. Polymorphic information content ranged from 0.41 to 0.84 , while heterozygosity ranged from $49 \%$ to $86 \%$, with an average value of $77 \%$. The association analyses performed between genotype classes for the genetic markers versus weight at first calving indicated no significant result. Also, no correlation was observed between calving interval (CI) and TGLA227 genotypes. However, positive associations were detected between ILSTSO02 and BMS3004 and CI. Animals carrying at least one ILSTS002*135 allele presented a CI about 39 days longer than the individuals with other genotypes; animals heterozygous for BMS3004 presented a CI about 35 days shorter than the homozygous. On these grounds, it can be concluded that these markers can be useful as an aid to fertility selection, in this herd.

Key words: microsatellites, reproduction, marker assisted selection, BTA 18.

\section{RESUMO}

Na fase de detecção, em um programa de seleção assistida por marcadores, em bovinos, este trabalho investigou a variabilidade genética de três microssatélites no cromossomo 18 (BTA 18). As possíveis associações entre genótipos ou alelos destes marcadores versus o peso ao primeiro parto e o intervalo entre partos (como indicadores do desempenho reprodutivo) foram avaliados em um rebanho de gado de corte (5/8 Aberdeen Angus x 3/8 Nelore). Onze alelos foram detectados em TGLA227 e ILSTS002 e três em BMS3004, os mais freqüentes sendo TGLA227*79, ILSTS002*133, ILSTS002*135 e BMS3004*129. O conteúdo polimórfico de informação variou de 0,41 a 0,84, enquanto $a$ heterozigosidade variou de 49 a 86\%, com média de $77 \%$. As análises de associação efetuadas entre classes genotípicas dos marcadores genéticos versus o peso ao primeiro parto não indicaram resultados significantes. Da mesma forma, nenhuma correlação foi observada entre o intervalo entre partos (IEP) e os genótipos de TGLA227. Entretanto, associações positivas foram detectadas entre ILSTS002 e BMS3004 com o IEP. Animais portadores de pelo menos um alelo ILSTS002*135 apresentaram IEP cerca de 39 dias mais longo que os indivíduos com outros genótipos, e animais heterozigotos para BMS3004 apresentaram IEP cerca de 35 dias mais curto que os homozigotos. Assim, pode-se concluir que esses marcadores podem ser úteis como auxiliares na seleção para fertilidade, o rebanho em questão.

Palavras-chave: microssatélites, reprodução, seleção assistida por marcadores, BTA 18.

\footnotetext{
IUniversidade Federal do Rio Grande do Sul (UFRGS), Porto Alegre, RS, Brasil.

IUniversidade Luterana do Brasil (ULBRA), Canoas, RS, Brasil.

IIIUniversidade Federal de Santa Maria (UFSM), Santa Maria, RS, Brasil.

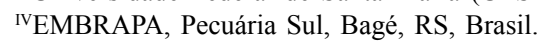

${ }^{v}$ Animal Reproduction and Biotechnology Laboratory, Department of Biomedical Sciences, Colorado State University,

Colorado, USA. *Corresponding author; address: Duque de Caxias 910, apto 101, 90010-280, Porto Alegre, RS, Brasil.

Phone: 0055513029 3594; Fax: 0055513029 3594. E-mail: taweimer@gmail.com.
} 
A possible strategy to improve the productive performance in livestock is the use of marker assisted selection (MAS), which means selecting for molecular markers in or around genes involved directly or indirectly in the expression of one desired character, usually a multifactorial trait (DAVIS \& DeNISE, 1998; SCHWERIN, 2001). According to DAVIS \& DeNISE (1998) there are three phases in the development of MAS programs, the detection phase, the evaluation phase, and the implementation phase; in the first one, direct markers or linked DNA polymorphisms are used to detect QTL segregation in a particular population.

Linkage analysis using short tandem repeats (STR) markers have been able to map a great number of QTL regions including loci responsible for diseases, carcass weight, milk production, conformation traits, and reproduction (for review see SCHWERIN, 2001).

In the detection phase of a bovine MAS program, the present study investigated the genetic variability of three STR mapped at bovine chromosome 18 (BTA 18) and evaluated the possible associations between genotypes of these markers and indicators of reproductive performance in a beef cattle herd.

Blood samples were collected from 166 cows with at least four parturitions records of a BrangusIbagé herd, a composite beef cattle (5/8 Aberdeen Angus x $3 / 8$ Nelore) resulting from the crossing between Aberdeen Angus cows (Bos taurus) and Nelore bulls (Bos indicus). This synthetic breed was created by the Brazilian Agricultural Research Corporation(EMBRAPAPecuária Sul, Bagé, RS, Brasil). Details of the population could be found in DUARTE et al. (2005). Genomic DNA was extracted from total blood by the method of MILLER et al. (1988). Three STR (BMS3004, ILSTS002 and TGLA227) mapped at BTA 18 were amplified by the polymerase chain reaction (PCR), as described by STEIGLEDER et al. (2004).

Allele and genotype frequencies were determined by gene counting, the parameters of genetic diversity within population [heterozygosity $(\mathrm{H})$ and polymorphic information content (PIC)] were estimated according to NEI (1978) and BOTSTEIN et al. (1980), respectively. One-way analysis of variance was employed to test associations between STR genotypes and average lifetime CI or WFC, according to the model: $\mathrm{Yij}=\mu+\mathrm{Ai}+$ eij, where: Yij is the CI or WFC phenotype of the jth individual; $\mu$ is the effect of the population mean; Ai is the effect of the ith genotype class; and eij is the random error component.

Calving interval did not present normal distribution, and it was previously corrected by using natural logarithm transformation. When a significant association was detected, the Tukey post hoc test was used to identify the significant group. To compare the significant group detected by ANOVA with the other genotypes, CI was dichotomized into classes consisting of animals with CI below or above the anti-mode value (549 days) and the frequencies were compared between these two groups by a $\chi^{2}$ test. The odds ratio (OR) with $95 \%$ confidence interval (ci) was obtained by logistic regression analysis. All the statistic analyses were performed using the SPSS ${ }^{\circledR}$ for Windows ${ }^{\mathrm{TM}}$ software (SPSS Inc), version 10.0.5 (1999).

Allele frequencies, genetic diversity parameters (PIC and $\mathrm{H}$ ) and descriptive statistics for the $\mathrm{CI}$ and WFC are presented in table 1. Eleven alleles were detected in TGLA227 and ILSTS002 and three in BMS3004. The PIC and $\mathrm{H}$ values were relatively high, the average heterozygosity being $77 \%$. The CI and WFC values did not differ among STR groups.

No association was found between genotype classes and WFC as well as between TGLA227 genotypes and CI. However, positive associations were detected between ILSTS002 and BMS3004 and CI. Animals carrying at least one ILSTS002*135 allele presented a CI about 39 days longer $(\mathrm{P}<0.05$; Table 2$)$ than animals with the other genotypes $(\mathrm{OR}=2.0, \mathrm{ci}=1.1-3.8, \mathrm{P}<0.05)$. With respect to the BMS3004, heterozygous animals showed a CI about 35 days shorter $(\mathrm{P}<0.054$; table 6$)$ than homozygous $(\mathrm{OR}=1.8, \mathrm{ci}=1.0-3.5, \mathrm{P}<0.10)$.

The reliability of the employment of CI to classify beef cattle mating seasonally remains unclear as observed in other studies in the same population (OLIVEIRA et al., 2002) and WFC may not be useful as a marker for fertility because it can be affected by environmental conditions that heifers were exposed to before the first mating. Despite these limitations $\mathrm{CI}$ is the most helpful criterion available to minimize environmental effects on cow fertility.

According to BOVMAP, there are 123 loci mapped on BTA 18 (http://locus.jouy.inra.fr/cgi-bin/ bovmap/intro.pl; access: 2006/04/20), the BMS3004, ILSTS002, TGLA227 being at 1.7, 54.7, $84.7 \mathrm{cM}$, respectively (U.S. Meat Animal Research Center, http:/ /www.marc.usda.gov/genome/ cattle/cattle.html; access: $2006 / 04 / 20$ ). Among the loci mapped at this chromosome the luteinizing hormone beta polypeptide $(\mathrm{LH} \beta)$ gene is directly involved on reproductive function. It is mapped at $48.2 \mathrm{cM}$ (National Center for Biotechnology Information, http:/ /www.ncbi.nlm.nih.gov; access: 2006/04/20), and therefore 46.5 and $6 \mathrm{cM}$ distant from BMS3004 and ILSTS002, respectively. Many studies have indicated that STR downstream or upstream gene sequences 
Table 1 - Allele frequencies, genetic diversity parameters (PIC and $\mathrm{H}$ ) and descriptive statistics for calving interval (CI) and cow weight at first calving (WFC) for three microsatellites in Brangus-Ibagé cattle.

\begin{tabular}{|c|c|c|c|c|c|}
\hline \multicolumn{2}{|c|}{ TGLA227 $\mathrm{n}=100$} & \multicolumn{2}{|c|}{ ILSTS002 n $=158$} & \multicolumn{2}{|c|}{$\mathrm{BMS} 3004 \mathrm{n}=163$} \\
\hline Alleles & Frequency & Alleles & Frequency & Alleles & Frequency \\
\hline 79 & 0.28 & 121 & $<0.01$ & 129 & 0.64 \\
\hline 81 & 0.07 & 123 & 0.01 & 132 & 0.31 \\
\hline 83 & 0.12 & 125 & 0.08 & 138 & 0.05 \\
\hline 85 & 0.08 & 127 & 0.02 & & \\
\hline 87 & 0.04 & 129 & 0.04 & & \\
\hline 89 & 0.16 & 131 & 0.15 & & \\
\hline 91 & 0.06 & 133 & 0.25 & & \\
\hline 93 & 0.04 & 135 & 0.25 & & \\
\hline 95 & 0.04 & 137 & 0.11 & & \\
\hline 99 & 0.04 & 139 & 0.06 & & \\
\hline 101 & 0.06 & 141 & 0.02 & & \\
\hline $\mathrm{H}$ & 0.86 & & 0.83 & & 0.49 \\
\hline PIC & 0.84 & & 0.81 & & 0.41 \\
\hline \multicolumn{6}{|l|}{$\mathrm{CI}$} \\
\hline Mean & 543.7 & & 544.9 & & 544.8 \\
\hline sd & 127.6 & & 119.8 & & 120.2 \\
\hline \multicolumn{6}{|l|}{ WFC } \\
\hline Mean & 352.4 & & 350.6 & & 351.3 \\
\hline $\mathrm{sd}$ & 53.8 & & 57.1 & & 56.9 \\
\hline
\end{tabular}

n: sample size; PIC: polymorphic information content; H: expected heterozygosity; sd: standard deviation. Average $\mathrm{H}=0.77$.

(even located at thousand cM from the target gene) play a significant role in gene regulation, by altering the primary, secondary or tertiary structure of DNA, by binding to transcription or translation factors, or by affecting RNA edition; they could be also in enhancer regions, and influence gene expression by altering the transcription complex assemblage (review in LI al., 2004). Considering the pivotal role of $\mathrm{LH}$ on

Table 2 - CI (and ln CI) for ILSTSO02* 135 carriers compared with the other animals and BMS3004 heterozygous compared with homozygous. Data are reported as mean \pm standard deviation.

\begin{tabular}{llll}
\hline ILSTS002 & $\mathrm{N}$ & Mean $\pm \mathrm{sd}(\mathrm{CI})$ & Mean $\pm \mathrm{sd}(\operatorname{lnCI})$ \\
\hline *135 carriers & 68 & $567.1 \pm 124.7$ & $6.32 \pm 0.2^{1}$ \\
other genotypes & 90 & $528.1 \pm 113.8$ & $6.25 \pm 0.2$ \\
& & & \\
BMS 3004 & & & \\
heterozygous & 97 & $530.7 \pm 120.9$ & $6.25 \pm 0.2^{2}$ \\
homozygous & 66 & $565.3 \pm 117.1$ & $6.32 \pm 0.2$ \\
\hline
\end{tabular}

${ }^{1}$ t test $(\ln \mathrm{CI})=2.1, \mathrm{P}<0.05$;

${ }^{2} \mathrm{t}$ test $(\ln \mathrm{CI})=2.1, \mathrm{P}<0.05$. reproduction, we cannot avoid to speculate whether the associations observed in the present study might be reflecting the effect of these STR on regulation of the LH $\beta$-chain gene or the even the possibility that these associations would be due to linkage disequilibrium with some LH $\beta$-chain gene mutation. It is also possible that these markers are influencing other gene loci indirectly involved on reproduction and mapped at BTA 18.

The association observed with the BMS3004 suggests the occurrence of molecular heterosis, which occurs when heterozygous for a specific polymorphism show a significantly greater or lesser effect for a quantitative or qualitative trait than homozygous, probably because heterozygotes show a broader range of gene expression (COMINGS \& MACMURRAY, 2000).

Although this paper developed only the MAS detection phase, and need go through the evaluation and implementation phases before its commercial use, it seems reasonable to suggest that ILSTS002 and BMS3004 markers could be useful to allow early selection of Brangus-Ibagé cows, improving the reproductive performance by reducing calving interval.

Ciência Rural, v.37, n.5, set-out, 2007. 


\section{ACKNOWLEDGEMENTS}

This work was supported by Programa de Apoio a Núcleos de Excelência (PRONEX), Fundação de Amparo a Pesquisa do Estado do Rio Grande do Sul (FAPERGS), Financiadora de Estudos e Projetos (FINEP) and Conselho Nacional de Desenvolvimento Científico e Tecnológico (CNPq).

\section{REFERENCES}

BOTSTEIN, D. et al. Construction of a genetic linkage map in man using restriction fragment length polymorphisms. American Journal Human Genetics, v.32, p.314-331, 1980 .

COMINGS, D.E.; MACMURRAY, J.P. Molecular heterosis: a review. Molecular Genetics and Metabolism, v.71, p.1931,2000 .

DAVIS, G.P.; DeNISE, S.K. The impact of genetic markers on selection. Journal of Animal Science, v.76, p.2331-2339, 1998.

DUARTE, L.B. et al. Diversity of microsatellites linked to the FSHß gene, their usefulness for individual identification and association with reproductive performance. Ciência Rural, v.35, p.145-149, 2005.

LI, Y.C. et al. Microsatellites within genes: structure, function, and evolution. Molecular Biology and Evolution, v.21, p.991-1007, 2004.

MILLER, S.A. et al. A simple salting out procedure for extracting DNA from human nucleated cells. Nucleic Acids Research, v.16, p.1215, 1988 .

NEI, M. Estimation of average heterozygosity and genetic distance in a small number of individuals. Genetics, v.89, p.583-590, 1978 .

OLIVEIRA, J.F.C. et al. Caracterização de aspectos produtivos de vacas Brangus-Ibagé com distintos graus de fertilidade. Ciência Rural, v.32, p.663-667, 2002.

STEIGLEDER, C.S. et al. Genetic diversity of a Brazilian Creole cattle based on fourteen microsatellite loci. Archivos de Zootecnia, v.53, p.3-11, 2004.

SCHWERIN, M. Molecular genome analysis in livestock at the beginning of the new millennium. Reproduction in Domestic Animals, v.36, p.133-138, 2001. 